\title{
Surfaces
}

\section{A REVIEW OF THE 1991 SESSION OF THE SCHOOL OF CRITICISM AND THEORY}

\section{Valeria Wagner}

Volume 1, 1991

URI : https://id.erudit.org/iderudit/1065265ar

DOI : https://doi.org/10.7202/1065265ar

Aller au sommaire du numéro

Éditeur(s)

Les Presses de l’Université de Montréal

ISSN

1188-2492 (imprimé)

1200-5320 (numérique)

Découvrir la revue

Citer ce compte rendu

Wagner, V. (1991). Compte rendu de [A REVIEW OF THE 1991 SESSION OF THE SCHOOL OF CRITICISM AND THEORY]. Surfaces, 1.

https://doi.org/10.7202/1065265ar 


\title{
A REVIEW OF THE 1991 SESSION OF
}

\section{THE SCHOOL OF CRITICISM AND THEORY}

\section{A CONFERENCE REVIEW}

\author{
Valeria Wagner
}

\begin{abstract}
"Extraordinary as it may seem, I believe in the existence of things" -- such was the substance, if not the exact form, of a statement made by Paul Fry during the question period after his lecture, "Literature as Insignificance", in which he elaborated a distinction between fiction and literature. The lecture was held shortly before the end of the six-week long program, by which time the participants were all in critical states of either mindlessness or mindfulness. Hence our reactions: some of us nodded in agreement with Professor Fry's belief; some of us turned to our neighbors in fear we had again missed the full import of the lecture, wondering WHAT things were in question; some scribbled furiously, others shuffled their feet in skeptical horror. Thinking back on the occasion, I am assailed by doubts. Did he think that we did not believe in the existence of things? Did he think that we thought that he did not? Did he really say that, or am I imagining things?
\end{abstract}

Were I able to reproduce faithfully the exact context to which Paul Fry's statement belongs much of its mystifying nature would fade. Retrospectively woven into the context of the series of very diverse lectures and colloquia which the school offered this year, Paul Fry's somewhat ancient words take on a more contemporary relevance. The day after his lecture Geoffrey Hartman talked on "The Holocaust: Limits of Literary Representation", and claimed that with the holocaust "reality has displaced phantasy". Geoffrey Hartman's argument relied heavily on Holocaust survivors' testimonies of disbelief in the horror they had witnessed -- "I cannot believe what my eyes have seen". Hartman argued that the sheer and unintelligible factuality of the Holocaust deprived the survivors of the possibility of an imaginary beyond from which to account for the here of the concentration camps, rendering what they witnessed unnarratable. Hence the limits of representation, and concurrently, the limits of belief. 
Dominick La Capra had already discussed the Holocaust as a "limit-case" challenging historicization in the opening colloquium paper, "Representing the Holocaust: Reflections on the Historians' Debate". La Capra's main argument was that to stress either the /pp 4-5/

uniqueness or the comparability of the Holocaust was to engage in one of the stages of a process of transference: a transference common to the revisionist historians' accounts of the "traumatic" event. The particularization or generalization of the historical event should thus be read in the light of the historians' individual historical positions, and historians should become aware of their personal involvement with the object of their study. Here what is in question is not so much of belief or disbelief in the potential deceitfulness of things, facts, events or texts, but rather, the subject's devious symbiosis with them.

Talking about an altogether different history, Jane Gallop was also concerned by the mechanisms of transference to which writers fall prey, though in her clinical hands these mechanisms took on the light of a compulsion to imitate and to repeat. In both her colloquium paper and lecture, Jane Gallop discussed feminist critics' slippages into the very authoritative voices and positions of power which their critical discourse should, in her opinion, undermine. Thus, as she shows in her talk, "The Attraction of Matrimonial Metaphor", feminist critics often fall back on matrimonial metaphors as metaphors of resolution or "happy endings", in spite of feminism's well founded distrust of the marriage institution. In Gallop's view, the social function of absorbing difference underlies marriage's promise to fulfill the psychic and social needs of individuals. We might say as much of the institution of academic writing, given academics' uncontrollable tendency to reproduce what they denounce. Much of the discussion period of Jane Gallop's talk and paper was in fact spent spotting her own prescriptions and conceptual weddings, in a rehearsal of our sophisticated De Manian awareness that there are no methods capable of containing our unawareness.

The other side of the coin of the subject's engulfment, its engulfment in the object of its attention, whether through introspective blindness or through transference, was Stanley Cavell's concern in his colloquium paper, "Emerson's Constitutional Amending", subtitled "Reading 'Fate'". For Cavell, /pp 5-6/

the fact that Emerson has insistently been disqualified as a philosopher raises the issue of what it means to read Emerson, which Cavell addressed in a discussion of the political implications of Emerson's essay "Fate". How could this essay be read, given Emerson's metaphorical use of the word "slave" despite its obvious literal meaning at a time when slavery was a major preoccupation in America as well as in other writings by Emerson himself? Linking Emerson to Heidegger "genealogically", Cavell suggested that philosophy, the philosophy he cares about, might very well be inherently 
compromised, and hence that the reading of it might be fateful. But such a fateful reading can only occur within the space of thought as a form of attention and listening, responsive to voice and to what Cavell calls Emerson's call for philosophy. The philosophy that Emerson calls upon is a philosophy of calling -- in Wittgenstein's words: it leaves things as they are. If the notions of transference and blindness testify to the object's resistance to discourse, a philosophy that yields to its resistance may witness a lasting change in the philosopher/reader.

As for us, lay participants and audience, immersed in visions of the resurgence of a "reality" that voraciously swallowed the remnants of our humanity, surrounded by talks of texts that threatened to hypnotise us into mimetism and would not let us grow into responsible readers and writers, well, we faltered. Deaf to Emerson's call, people dreamt of cats and bats and kitchen tables. One of the feelings in the air was that this criticism-andtheory might be serious stuff or, again, it might not. The term "mourning" became common currency. The term "fetishism" came to our rescue.

It all began at the beginning of the program, with Teresa de Lauretis's claim that it is possible to account for lesbian desire with the Freudian model of fetishism. Instead of denying the import of the castration complex for lesbianism, De Lauretis stressed what is probably one of its most interesting consequences: the realization that substitution and displacement are viable solutions. Through a close reading of different texts written by lesbians, she showed that what lesbian desire fetishizes is the whole body in its different

/pp 6-7/

appearances -- clothes, gestures, attitudes, etc. Teresa De Lauretis' deflection of fetishism towards the female subject and the ensuing subject/ object conflation promises to upset the traditional object of psychoanalysis, the subject. Her lectures, difficult and controversial, proved to be upsetting enough for us throughout the six weeks of the course. But fetishism survived as a way of mourning criticism and theory, in the context of the school.

For Wendy Steiner, who conducted a seminar on Aesthetic Fetishism, and gave a paper on the same subject, fetishism is the basic relationship between critics and the art objects of their concern. The series of theories that have successively captivated academics have all failed to constitute art as a proper object of knowledge. Ultimately, as reader and writer, the critic assesses the art object on the grounds of an inescapable "I like it". The critic's evaluation does not bear on the art object itself, rather, it is a measure of its substitutive qualities. Far from condemning the critic's fetishism, Wendy Steiner argues that to yield to the art object's power over oneself is not only a domineering transference of power but also an act of public recognition and remembrance of -- presumably -- a common past and loss. Instead, the critic's pseudo-scientific objectivation of art is deceitful and enhances the (reality) gap between academia and the rest of society. Wendy Steiner was the only lecturer to refer to what must be a familiar preoccupation if not nightmare to academics: that "we" (academics) might 
not be talking about the same thing as "them" (non-academics, or "the rest"), that "we" might be making it up and the real "it" may be freely , roaming out there.

Stanley Cavell's vindication of Emerson (echoed by Richard Poirier), Jane Gallop's denunciation of mechanisms of marginalization, La Capra's concern with the effects of transference on the historian's discourse, Wendy Steiner's outright skepticism with regard to academia, the lectures and lecturers that have wisely escaped from this account -- all these positions easily build up into a by now familiar critique of the politics of inclusion, exclusion, and production of knowledge of the academic institution, and of its self-/pp 7-8/

marginalization from "the rest of society". These positions also reflect the tension that is inherent to the juxtaposition of terms such as criticism and theory, as the passage from one to the other, or the interaction between them, necessarily entails some kind of loss of their respective discursive objects. This is the phenomenon that Dominick La Capra pointed out as he linked the process of transference to the stress on either the unicity or comparability of the Holocaust. In Stanley Cavell's terms, the shift from the specific to the generic is an enabling condition for the philosopher's skepticism. But lurking behind the generic questions of whether the world really does exist and whether it comprehends the objects of criticism and theory might be the more specific question of whether the world will continue to exist, with or without the cooperation of schools of academics. Here the issues of loss and displacement are articulated in terms of the individual and the community, with the inevitable (and mutual) double-bind of belonging and exclusion. Whatever school we partake in we will also be fish out of its compromised waters. And this, taking up Stanley Fish's words, "is a good thing too!" -- that the academia is compromised, theory and criticism are compromised, and we are all compromised. If this wasn't the case, then we would have lost what makes the School of Criticism and Theory worth attending, even several times.

\section{Université de Genève}

22, Bld. des Philosophes - 1211 Genève4 - Suisse

Surface Page d'Acceuil/Home Page 